\title{
The human hexokinase II gene promoter: functional characterization and detection of variants among patients with NIDDM
}

\author{
M. Malkki ${ }^{1,2} \cdot$ M. Laakso ${ }^{2}$. S.S. Deeb ${ }^{1}$ \\ ${ }^{1}$ Departments of Medicine and Genetics, University of Washington, Seattle, Washington, USA \\ ${ }^{2}$ Department of Medicine, Kuopio University Hospital, Kuopio, Finland
}

\begin{abstract}
Summary Hexokinase II (HKII) plays an important role in facilitating glucose uptake by skeletal muscle, heart, and adipose tissue in response to insulin. We have cloned and sequenced the proximal promoter region of the human HKII gene, determined the transcription start sites and screened the $2.0 \mathrm{~kb}$ of the proximal 5 ' flanking region for variants in non-insulin-dependent diabetic patients and control subjects. We found three variants in this region, one in the $5^{\prime}$ untranslated region $(\mathrm{G} \rightarrow \mathrm{C}$ at +217$)$ and two in the promoter region $(\mathrm{T} \rightarrow \mathrm{G}$ at -1043 and $\mathrm{G} \rightarrow \mathrm{A}$ at -1159). The allele frequencies of these variants did not differ between the diabetic and control subjects and these variants are not associated with insulin resistance. Various segments of the human HKII promoter were tested for driving expression of the luciferase reporter gene. The proximal $500 \mathrm{bp}$ and 400
\end{abstract}

bp of the promoter were sufficient to drive maximal activity in adipocyte (3T3F442A) and myocyte $(\mathrm{C} 2 \mathrm{C} 12 \mathrm{~F} 3)$ cell lines, respectively. This region of the promoter is GC-rich and contains eight consensus binding sites for the transcription factor $\mathrm{Sp}-1$, five for AP-2, two putative response elements for each of insulin and cyclic AMP. The proximal 175 bases of the promoter retained only $7-15 \%$ of maximal activity. Sequence elements located between positions -304 and -215 accounted for approximately $80 \%$ of the basal HKII promoter. In addition, the region between -215 and -184 contains a negative regulatory element for expression in 3T3F442A but not in C2C12F3 cells. [Diabetologia (1997) 40: 1461-1469]

Keywords Hexokinase II, promoter, NIDDM, insulin resistance, diabetes mellitus.
The isoenzymes of hexokinase (I-IV) (ATP: D-hexose 6-phosphotransferase EC 2.7.1.1) (reviewed in reference [1]) catalyse the first step in intracellular glucose metabolism, the phosphorylation of glucose to glucose 6-phosphate. HK isozymes I-III have high affinity for glucose and are feedback inhibited by glucose 6-phosphate, whereas HK IV (glucokinase) is

Received: 8 May 1997 and in revised form: 22 July 1997

Corresponding author: Dr. S. Deeb, Genetics Department Box 357360, University of Washington, Seattle WA 98195, USA Abbreviations: HKII, Hexokinase II; NIDDM, non-insulin-dependent diabetes mellitus; kb, kilobases; SSCP, single strand conformation polymorphism; IRE, insulin responsive element; CRE, cyclic AMP responsive element; PEPCK, phosphoenolpyruvate carboxykinase; GAPDH, glyceraldehyde 3phosphate dehydrogenase. not. The glucose phosphorylation step may be rate limiting and, therefore, hexokinases may play a pivotal role in the regulation of glycolysis.

Hexokinase II (HKII) is primarily expressed in insulin-sensitive tissues such as skeletal and cardiac muscle and adipose [2-5]. The cDNA sequence and the structure of the rat [5, 6] and human [7-9] HKII genes have been determined. The human HKII gene spans at least $52 \mathrm{~kb}$ and is comprised of 18 exons which encode a protein of 917 amino acids. The human gene has been mapped to 2p13.1 [10].

Insulin was shown to increase HKII mRNA levels by 2 to 3 -fold and by 6 -fold in differentiated skeletal muscle (C2C12, L6) and adipocyte (3T3F442A, BFC-1B) cell lines [5], respectively. This increase was shown to result from transcriptional activation of the gene in L6 cells. In addition, catecholamines and cyclic AMP were shown to induce expression of 


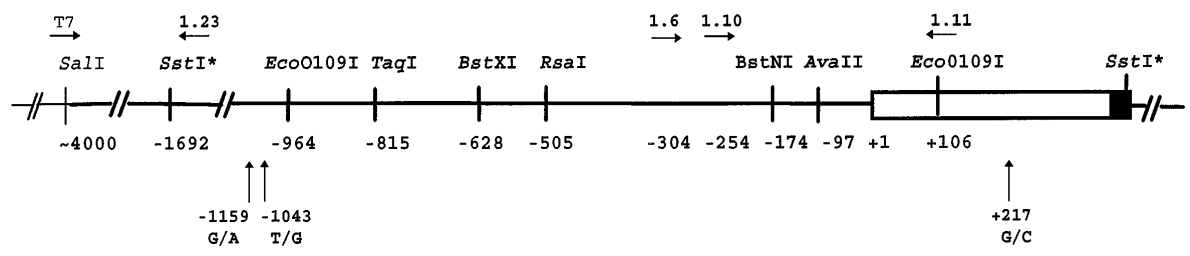

Fig. 1. Partial restriction map of HKII promoter indicating $5^{\prime}$ ends of nested deletions. Shown are genomic clone HKII-L19 and the $2.2 \mathrm{~kb}$ SstI subclone derived from this clone (asterisks). Nested deletions have the same 3 ' end at +106 and various $5^{\prime}$ ends (vertical lines). The location of PCR primers indicated by horizontal arrows. Sequence variants indicated by vertical arrows. Open and solid rectangles represent untranslated region of exon 1 and coding region of HKII, respectively. Transcription start site is indicated with +1

the HKII gene in L6 and BCF-1B cells which led to an increase in glucose phosphorylation [11]. Hyperinsulinaemia was observed to be associated with elevated HKII mRNA levels in rat skeletal muscle and adipose tissue [12] and in human skeletal muscle [13]. On the other hand, hyperglycaemia was not found to influence HKII expression in these tissues in the rat [12].

In the $\mathrm{KKA}^{\mathrm{Y}}$ mouse, an animal model of non-insulin-dependent diabetes mellitus (NIDDM), HKII mRNA and protein levels are significantly reduced in adipose tissue and skeletal muscle [14]. Furthermore, reductions in basal levels of glucose 6-phosphate [15], in insulin-stimulated glucose uptake (reviewed in reference [16]), and in the levels of HKII mRNA and enzyme production were observed [17] in skeletal muscle of NIDDM patients, suggesting a defect in glucose phosphorylation.

The human HKII gene has been screened for mutations in the coding region, and a total of 7 amino acid substitutions were found [18-21]. Although some of these substitutions may be associated with risk for NIDDM or insulin resistance, they are too infrequent to account for potentially more than 1-2\% of NIDDM cases. The regulatory sequences of the human HKII gene have not been screened. Genetic variability in response of the HKII gene to insulin may underlie insulin resistance in skeletal muscle and adipose tissue. Therefore, we screened the proximal promoter of the human HKII gene for variants that may potentially play an important role in its expression in these tissues and in response to various regulatory agents.

The activity of the proximal rat tumour-type HKII promoter has been studied by transient transfection experiments in rat hepatocytes and hepatoma cells $[22,23]$. The HKII gene is not normally expressed in the liver, however, it is expressed at high levels in a variety of rapidly growing tumour cells, including hepatoma cells, which have a high glucose catabolic rate [24]. In attempts to define the molecular basis of this marked elevation in transcription of this gene in hepatoma cells, Ichihara et al. [22] performed transient transfection of hepatoma cells with plasmids containing various lengths $(0.1,0.6$, and $1.3 \mathrm{~kb})$ of the rat HKII promoter. They found that the plasmids containing the 1.3 and $0.6 \mathrm{~kb}$ had similar activities, whereas the $0.1 \mathrm{~kb}$ construct was almost completely inactive, indicating the presence of important cis-regulatory elements within the proximal $600 \mathrm{bp}$ of the transcription start site. In a second study, Mathupala et al. [23] transfected hepatoma cells with a plasmid containing $4.3 \mathrm{~kb}$ of the rat proximal HKII promoter (tumour-type) and showed that promoter activity was enhanced upon treatment with glucose, insulin, glucagon, phorbol 12-myristate 13-acetate (PMA) and cyclic AMP. Incubation in the presence of insulin and glucose together resulted in maximal activation. However, these compounds had no effect on transcription of the endogenous HKII gene in primary hepatocytes and did not activate the $4.3 \mathrm{~kb}$ proximal promoter upon transient transfection of primary hepatocytes.

We have initiated characterization of the activity of the human HKII promoter in cell types that express the endogenous gene, namely skeletal muscle and adipose tissue. We have cloned and sequenced the human proximal promoter, determined the transcription start sites of the gene, screened for variants in NIDDM patients and control subjects, and performed analysis of promoter activity in skeletal muscle and adipocyte cell lines. We have identified certain regions of the proximal promoter that play major roles in its activity in these two types of cells.

\section{Subjects, materials and methods}

Isolation, sequencing and characterization of genomic clones that span the human HKII promoter. Isolation of human HKII genomic clones that contain exon 1 has been described [8]. Six of these genomic clones which hybridized to a $112 \mathrm{bp}$ cDNA probe $(-52$ to +60 with respect to the translation start site) were tested for the presence of promoter sequences. Exon 1 contains a unique Sst I site (Fig.1), therefore, these clones were digested with Sst I and subjected to Southern blot analysis using the same probe. Two of these clones (HKII-L19 and L-29) were chosen because they yielded the longest Sst I fragments (Fig. 1). The hybridizing Sst I fragments $(0.9 \mathrm{~kb}$ from clone HKII-L29 and $2.2 \mathrm{~kb}$ from clone HKII-L19) were subcloned into the vector pGEM-3Zf( + ) (Promega, Madison, Wis., USA) and sequenced (Sequenase kit; US Biochemicals, Cleveland, Ohio, USA). The $0.9 \mathrm{~kb}$ Sst I subclone extended 
Table 1. Sequence and location of primers used for PCR amplification

\begin{tabular}{lll}
\hline Primer & Sequence $\left(5^{\prime}-3^{\prime}\right)$ & Position \\
\hline HKII 1.1 & CCGAGGCGGAGACGCGAGAG & $+416 /+397^{\mathrm{a}}$ \\
HKII 1.10 & CCAGCCTTTAGCCACGGAC & $-254 /-236$ \\
HKII 1.37 & GGCTACCGGCGAGGGTGC & $+310 /+297$ \\
HKII 1.38 & CTGTGAATCGGAGAGGTC & $+92 /+109$ \\
HKII 1.28 & GGCCTTGCCACAATTTCCTC & $-606 /-587^{\mathrm{b}}$ \\
HKII 1.33 & GTCCGTGGCTAAAGGCTGG & $-236 /-254$ \\
HKII 1.22 & CCTTCATCTTCCTTCCCTG & $-1325 /-1307^{\mathrm{c}}$ \\
HKII 1.15 & GAGGAAATTGTGGCAAGGCC & $-587 /-606$ \\
HKII 1.34 & TTTGGAGTCTGGTGTCTACC & $-1194 /-1175$ \\
HKII 1.35 & TGCTGCCTCTCTAAGAGCC & $-990 /-1008$ \\
HKII 1.6 & CCCACCCATAGCCGAGCCT & $-304 /-286$ \\
HKII 1.11 & GGGCAGTGGGACCTCTCCGATTCA & $+118 /+95$ \\
HKII 1.23 & AGATTTCAAGAGACATGAC & $-1244 /-1262$ \\
LUC MC5 & TCTGGATCCAAGCTCAGATC & \\
LUC MC3 & TACCAACAGTACCGGAATGCC & \\
\hline
\end{tabular}

${ }^{a}$ PCR product generated from this pair of primers was digested with Eco0191 and Bgll to generate fragments of 148, 212, 182 and 128 bp prior to SSCP analysis;

$\mathrm{b}$ PCR product amplified from this pair of primers was digested with Banl to generate fragments of 192 and 179 bp before SSCP analysis;

${ }^{\mathrm{c}}$ PCR product generated from this pair of primers was digested with Pstl to generate fragments of 286, 220, and $233 \mathrm{bp}$ prior to SSCP analysis. Primers labelled LUC MC5' and $3^{\prime}$ correspond to sequences of the multiple cloning site of the luciferase plasmid vector

from the multiple cloning site of the vector $\lambda$ FIX (Srategene, La Jolla, Calif., USA) to the Sst I site in exon 1.

In order to determine whether genomic clone HKIIL19 had additional sequences 5' upstream of the distal Sst I site (Fig. 1), this clone was used as template for PCR amplification using vector primer T7 and HKII primer 1.23 (Table 1, Fig. 1) using the Expand Long Template PCR System (Boehringer Mannheim, Indianapolis, Ind., USA) according to the manufacturer's protocol. An amplification product of approximately $2.7 \mathrm{~kb}$ was obtained.

Determination of the transcription initiation site. The transcription initiation site of the human HKII gene was determined by primer extension analysis [25]. Total cellular RNA from human skeletal muscle and adipose tissue samples was isolated using the guanidinium isothiocyanate-phenol-chloroform method [26]. The antisense oligonucleotide primer 5'GCGGATTTTCTTAGCTGGGTG-3', position -376 to -396 with respect to the translation start site (underlined in Fig. 2) was used in primer extension analysis as previously

Fig. 2. Sequence of 5 '-flanking region of human HKII gene. Proximal $540 \mathrm{bp}$ of the rat HKII promoter aligned with human promoter sequence (conserved nucleotides marked with vertical lines). The transcription initiation site marked with +1 . Putative TATA-like box and CAAT box are in bold; the two Alu repeats in lower case. Putative transcription factor binding sites (underlined) were identified by comparison with sequences in the "Transcription Element Search Database" (http:// agave.humgen.upenn.edu/cgi-bin/tess). The oligonucleotide primer used for primer extension analysis is double underlined

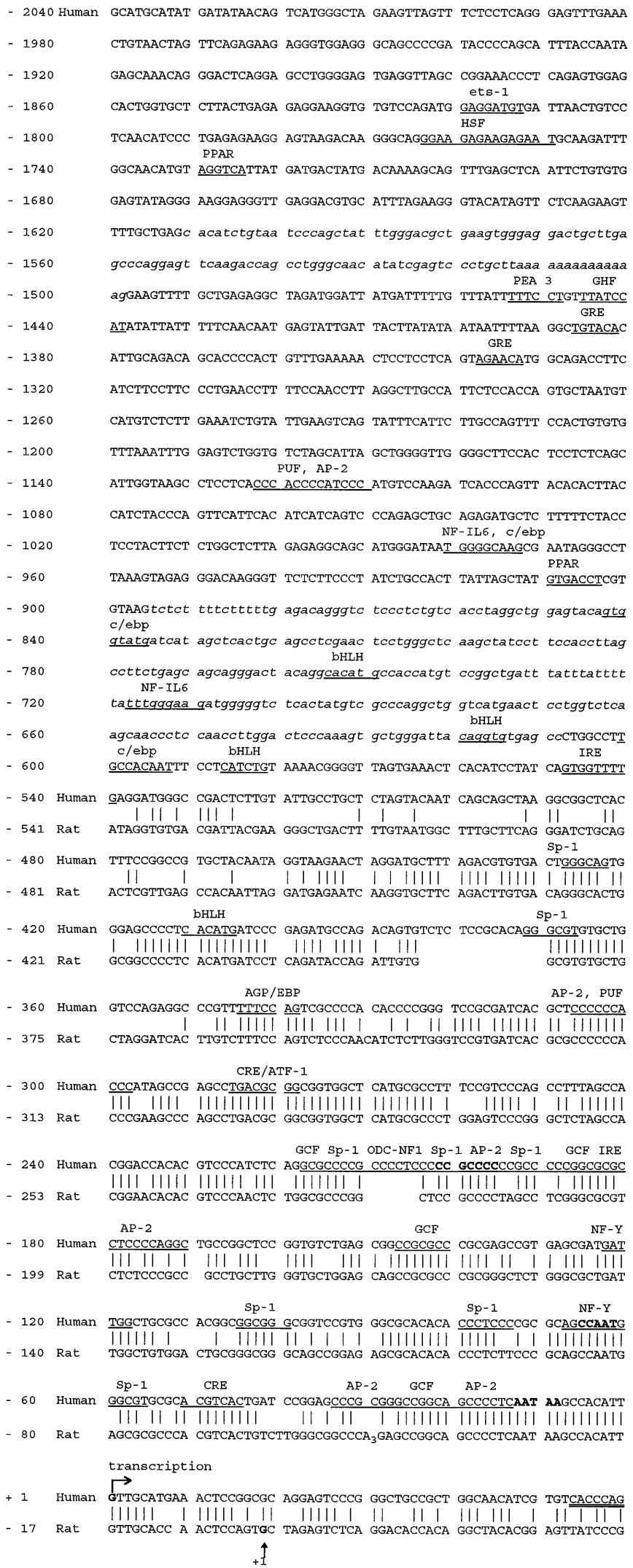

+ 61 Human CTAAGAAAAT CCGCGGGCCC GAGCCACGCG CCTGTGAATC GGAGAGGTCC CACTGCCCGA +121 GTGGAGCCGG GCTGAGATTC TTCTCAAGTT GAGCCTCAGT GATCCTGTGG CCGAAGTTAG +181 CGCCTTGACG TGGGACAACC GGACACGTCG CCAGGAGAGA ACTGAGGCGC CTTCTAGCAG +241 TTGTGACGCC AAAATCACGT CTCCGGAGAC CCGCGCCCTC CGCCAGCCGG GCGCACCCTC +361 CAGCACAAAG CAGTCGGACC GCGCCGCCCG CCTCCCCTCT CGCGTCTCCG CCTCGGTTTC $\stackrel{\text { translation }}{\longrightarrow}$

+421 CCAACTCTGC GCCGTCGGGC CGCGGCAGGA TGATTGCCTC GCATCTGCTT GCCTACTTCT 
described [5]. The procedure was modified as follows: $25 \mu \mathrm{g}$ of RNA was annealed at $62^{\circ} \mathrm{C}$ for $16 \mathrm{~h}$, extension was done at $42^{\circ} \mathrm{C}$ for $1 \mathrm{~h}$ using $400 \mathrm{U}$ of SuperScriptII reverse transcriptase (BRL, Grand Island, N.Y., USA) and the reaction products were electrophoresed on an $8 \%$ polyacrylamide-7 Murea-sequencing gel. A sequencing ladder was generated using the $0.9 \mathrm{~kb}$ Sst I fragment derived from genomic clone L29 as template and the same labelled oligonucleotide as primer.

Screening for variants and association of variants with insulin sensitivity. The screening for variants in the promoter region and in the $5^{\prime}$ untranslated region of the HKII gene was performed by single strand conformation polymorphism (SSCP) analysis and sequencing of variants as previously described [20]. The primers and restriction enzymes used in SSCP analysis are shown in Table 1.

The association of variants with insulin sensitivity was determined in 112 patients with NIDDM (56 men, 56 women, age $63 \pm 1$ years, body mass index $30 \pm 1 \mathrm{~kg} / \mathrm{m}^{2}$, duration of diabetes $8 \pm 1$ years, $49 \%$ treated with diet, $29 \%$ with oral drugs and $22 \%$ with insulin) and in 97 control subjects with normal glucose tolerance ( 84 men, 13 women, age $55 \pm 1$ years, body mass index $27 \pm 0 \mathrm{~kg} / \mathrm{m}^{2}$ ). Insulin sensitivity was determined by the euglycaemic hyperinsulinaemic clamp technique (insulin infusion of $80 \mathrm{mU} \cdot \mathrm{m}^{-2} \cdot \mathrm{min}^{-1}\left(480 \mathrm{pmol} \cdot \mathrm{m}^{-2} \cdot \mathrm{min}^{-1}\right)$ in control subjects and $120 \mathrm{mU} \cdot \mathrm{m}^{-2} \cdot \mathrm{min}^{-1}\left(720 \mathrm{pmol} \cdot \mathrm{m}^{-2}\right.$. $\mathrm{min}^{-1}$ ) in patients with NIDDM) as previously described in detail [27].

Preparation of nested deletions of the HKII promoter. Starting with the 0.9 and $2.2 \mathrm{~kb}$ Sst I-subclones of genomic clones L29 and L19, respectively, nested deletions of the HKII promoter were generated either by cutting with the restriction enzymes shown in Figure 1 (with the 3 ' end of all segments generated by cleavage with Eco0109I) or by PCR amplification of the desired segment. The sequence of oligonucleotide primers used for PCR amplification is given in Table 1. Digested samples were blunt-ended and purified by electrophoresis on a $1 \%$ low-melting-point agarose gel followed by Qiaex gel extraction purification (Qiagen Inc., Chatsworth, Calif., USA) and cloned into the SmaI site of the luciferase reporter vector PXP1 (ATCC \#37576, [28,29]).

The $-4.0 \mathrm{~kb}$ HKII construct was prepared in two steps. First,

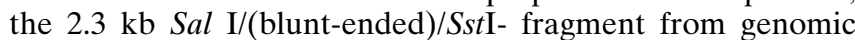
clone L19 was cloned into the BamHI (blunt-ended)-Sst I site of PXP1 vector. This subclone was designated luc $-4.0 /-1.7$. Next, a $1.8 \mathrm{~kb}$ Sst I/Eco0109I fragment (Fig. 1, -1692 to + 106) was isolated, the EcoO109I-end blunted and cloned into the Sal I(blunt-ended)-Sst I site of subclone luc $-4.0 /-1.7$ resulting in the $-4.0 \mathrm{~kb}$ HKII construct.

The sequence of all nested deletions was determined using vector primers LUC-MC5 ' and LUC-MC3 ' (Table 1) and several HKII promoter primers. The $3^{\prime}$ ends of the nested deletion clones extended to nucleotide +106 . Plasmid DNA for transfection experiments was prepared using the Qiagen plasmid kit (Qiagen Inc) according to the manufacturer's protocol.

Internal deletions of various lengths of the GC-rich region located between positions -215 and -180 were frequently observed when we attempted to amplify, using genomic clones as templates, segments encompassing this region. One of these deletions (between -215 and -184) was also used in transfection assays.

Cell culture and transient transfection. The mouse myoblast cell line $\mathrm{C} 2 \mathrm{C} 12 \mathrm{~F} 3$ [30], kindly provided by Dr. H. Weintraub's laboratory (Fred Hutchinson Cancer Research Center, Seattle, Wash., USA), was maintained in Dulbecco's modified Eagle's medium (DMEM) supplemented with $2 \mathrm{mmol} / \mathrm{l}$ L-glutamine and $20 \%$ fetal bovine serum in a $5 \% \mathrm{CO}_{2} /$ air environment at $37^{\circ} \mathrm{C}$. Cells were induced to differentiate into myotubes in DMEM medium supplemented with $2 \%$ horse serum. Approximately $90 \%$ of cells were differentiated into multinucleate myotubes after 3 days of culture in differentiation medium.

The mouse preadipocyte cell line 3T3F442A [31], kindly provided by Dr. M. Reina (University of Barcelona, Spain), was grown in DMEM supplemented with $2 \mathrm{mmol} / \mathrm{l} \mathrm{L}$-glutamine, $8 \mathrm{mg} / \mathrm{l}$ biotin, $15 \mathrm{mmol} / \mathrm{l}$ Hepes and $10 \%$ fetal bovine serum. Cells were differentiated into adipocytes in growth medium further supplemented with $2 \mathrm{nmol} / \mathrm{l} \mathrm{T}_{3}$ and $17 \mathrm{nmol} / \mathrm{l} \mathrm{bo-}$ vine insulin. Differentiation was followed by staining lipid droplets with Red Oil O.

Both cell lines were transfected in 24-well plates using the lipofectin reagent (BRL, Grand Island, N. Y., USA) basically following the manufacturer's protocol. Before harvesting, C2C12F3 and 3T3F442A cells were kept in differentiation medium for 1 and 4 days respectively.

For insulin induction studies, $\mathrm{C} 2 \mathrm{C} 12 \mathrm{~F} 3$ and 3T3F442A cells were transfected and then maintained in differentiation medium for 3 to 5 days, after which they were incubated for 8 to $48 \mathrm{~h}$ in serum-, insulin- and glucose-free or glucose-containing growth medium. Subsequently, $10-100 \mathrm{nmol} / \mathrm{l}$ insulin, $25 \mathrm{mmol} / \mathrm{l}$ glucose or both together were added into the medium and the cells incubated for an additional 4 to $48 \mathrm{~h}$. Cells were harvested, washed once with phosphate buffered saline and lysed with $100 \mu \mathrm{l}$ of lysis reagent (Promega, Madison, Wis., USA). We used $10 \mu \mathrm{l}$ of the cell lysate to determine protein concentration [32]. Luciferase and $\beta$-galactosidase activities were determined using $20 \mu \mathrm{l}$ of the cell extract as previously described [33]. Each experiment included two independent control transfections. A promoterless vector, PXP1, was used to correct for background activity and a luciferase reporter gene driven by Rous sarcoma virus promoter, pRSVL 5' [28], was used as an external standard to which HKII promoter activities were compared. The plasmid pnCMVlacF, a lacZ reporter gene driven by the cytomegalovirus promoter/enhancer, was used to correct for differences in transfection efficiency.

\section{Results and discussion}

Sequence and functional properties of the human HKII gene promoter. We have isolated the proximal promoter of the human HKII gene and sequenced $2.0 \mathrm{~kb}$ immediately upstream of the transcription initiation site (Fig.2). Alignment of the human and rat promoter sequences revealed high conservation up to $450 \mathrm{bp}$ upstream of the transcription initiation site (Fig. 2). The promoter sequence was analysed for transcription factor binding sites using the "Transcription Element Search" database (http://agave.humgen.upenn.edu/cgi-bin/tess). The human HKII promoter has a TATA-like box (AATAA) at position -13, a CCAAT-box at -66, and an inverted CCAATbox (also referred to as a Y-box) at position -118 (Fig.2). The proximal $550 \mathrm{bp}$ region of the promoter is GC-rich and contains eight putative consensus binding sites for the Sp-1 family of transcription factors $[34,35]$. The human HKII promoter also contains five putative binding sites for AP-2 [36,37], four for GCF [38], two for CTF-NF-Y ([39-42] for review see 
[43]) and one for ODC-NF-1 [44]. In addition, there are two putative cyclic AMP (CRE) and two insulin response elements (IRE) within this proximal region.

The ubiquitously expressed heteromeric transcription factor NF-Y binds to the CCAAT and Y-boxes and activates transcription of a variety of genes [3942]. GCF and ODC-NF1 were shown to interact with GC-rich regions and repress transcription from promoters of the epidermal growth factor receptor, $\beta$-actin, calcium-dependent protease and ornithine decarboxylase genes $[38,44]$. A protein kinase A-dependent signal transduction pathway was proposed to mediate regulation of transcription of the PEPCK and tyrosine aminotransferase gene promoters by insulin via a cAMP response element (CRE) [45-47].

Osawa et al. [48], recently observed that cAMP induces activity of a reporter gene driven by rat HKII promoter constructs. Furthermore, they showed that the CCAAT box and an adjacent CRE cumulatively mediate the inductive effect of cAMP. Both of these elements, including the spacing in-between, are completely conserved in the human HKII promoter (at -44 for CRE and -62 for CCAAT in Fig. 2). The potential role of these putative transcription factors on the regulation of human HKII gene remains to be established.

The human (but not the rat) HKII promoter was found to contain one complete and one truncated Alu repeat elements (lower case letters in Fig. 2) which belong to the relatively old J-subfamily of Alus $[49,50]$. The upstream Alu is truncated at its $3^{\prime}$ end by approximately $195 \mathrm{bp}$ and is flanked by $14 \mathrm{bp}$ direct repeats and is oriented in the opposite direction of the complete downstream Alu element.

The transcription initiation sites of the human HKII gene. Primer extension analysis was used to determine the transcription start site(s) of the human HKII gene. An end-labelled HKII antisense oligonucleotide primer, from -376 to -396 with respect to the translation start site (underlined in Fig.2), was hybridized to total RNA prepared from human skeletal muscle or adipose tissue and extended by reverse transcription. The length of the resulting fragments indicated a major transcription initiation site of 449 bp upstream of the translation initiation codon (Fig. 3). In skeletal muscle there were minor sites at $-12,-20,-39,-40$ and -41 , which were not observed in adipose tissue. These results differ from those reported for the rat HKII [5] in which the transcription initiation site in rat adipose tissue was mapped to position +19 with respect to the major start site in human tissues (Fig. 2). Additional start sites were found at positions $+18,+16,+15,-4$ and -5 (with respect to the start site in human HKII) in the rat AH130 hepatoma cell line [22]. The potential role of these different initiation sites remains to be established.

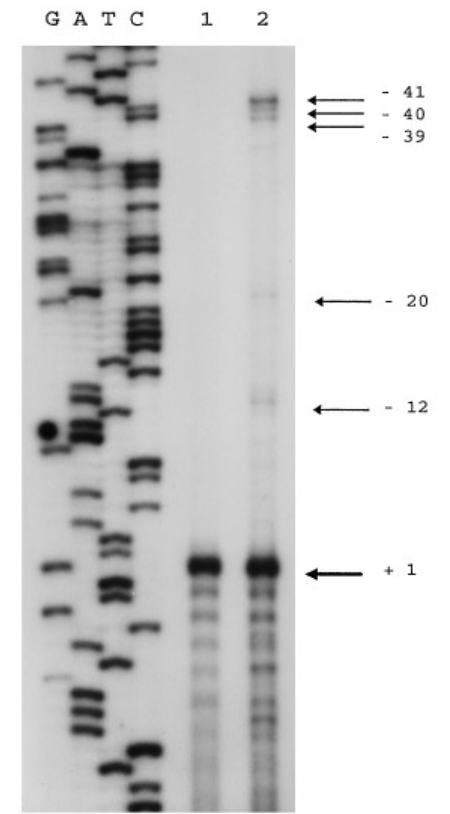

Fig. 3. Primer extension analysis with human adipose tissue and skeletal muscle RNA. A ${ }^{32}$ P-labelled oligonucleotide primer (Fig. 2) was hybridized with $25 \mu \mathrm{g}$ of total RNA extracted from human adipose tissue (lane 1) and skeletal muscle (lane 2). The extended products were run on an $8 \%$ sequencing gel adjacent to the DNA sequencing ladder generated by the same labelled oligonucleotide with a subclone of the human hexokinase gene as template. The major band is marked with a thick arrow and minor sites with thin arrows

Sequence variants of the promoter region. SSCP analysis revealed the previously reported variant $\mathrm{G} \rightarrow \mathrm{C}$ at position +217 [21] in the $5^{\prime}$ untranslated region and two new variants in the promoter region of the HKII gene $(\mathrm{T} \rightarrow \mathrm{G}$ at position -1043 and $\mathrm{G} \rightarrow \mathrm{A}$ at position -1159) (Fig. 1). The frequency of the $\mathrm{C}$ allele at position +217 was 0.183 in patients with NIDDM and 0.268 in control subjects $(p=\mathrm{NS}$ between the groups). The allele frequency of the $\mathrm{T} \rightarrow \mathrm{G}$ substitution at position -1043 (Fig. 1) was 0.03 in patients with NIDDM and 0.06 in control subjects and the allele frequency of the substitution $\mathrm{G} \rightarrow \mathrm{A}$ at position -1159 (Fig. 1) was 0.473 in patients and 0.464 in control subjects ( $p=\mathrm{NS}$ between groups). None of these variants was associated with high fasting, 1-h or 2-h insulin levels (data not shown). The association of the +217 and -1159 variants with insulin resistance was evaluated by the euglycaemic clamp. Neither of these variants was associated with low rates of whole body glucose uptake in NIDDM or control subjects (Table 2). In addition, the -1043 variant $(\mathrm{T} \rightarrow \mathrm{A})$ was not associated with reduced rates of whole body glucose uptake (data not shown). Thus, it seems unlikely that any of these variants contributes to insulin resistance.

Functional analysis of the HKII promoter. A series of nested $5^{\prime}$ deletions of the HKII promoter driving 
Table 2. Rate of whole body glucose uptake as a function of genotype at the promoter region

\begin{tabular}{llllll}
\hline & \multicolumn{2}{l}{ Variant at +217} & & \multicolumn{2}{l}{ Variant at -1159} \\
\cline { 2 - 3 } \cline { 5 - 6 } & GG & & GG & GA/AA \\
\hline Control subjects & $58.7 \pm 2.2(41)$ & $55.1 \pm 2.1(29)$ & & $58.3 \pm 3.8(17)$ & $56.8 \pm 1.7(53)$ \\
NIDDM patients & $27.5 \pm 1.9(16)$ & $30.0 \pm 5.0(7)$ & & $30.6 \pm 2.7(11)$ & $26.2 \pm 2.9(12)$ \\
\hline
\end{tabular}

Rates of whole body glucose uptake $\left(\mu \mathrm{mol} \cdot \mathrm{kg}^{-1} \cdot \mathrm{min}^{-1}\right)$, as evaluated by the euglycaemic clamp technique, of control and NIDDM patients with different genotypes at the $\mathrm{G} \rightarrow \mathrm{C}$ (posi-

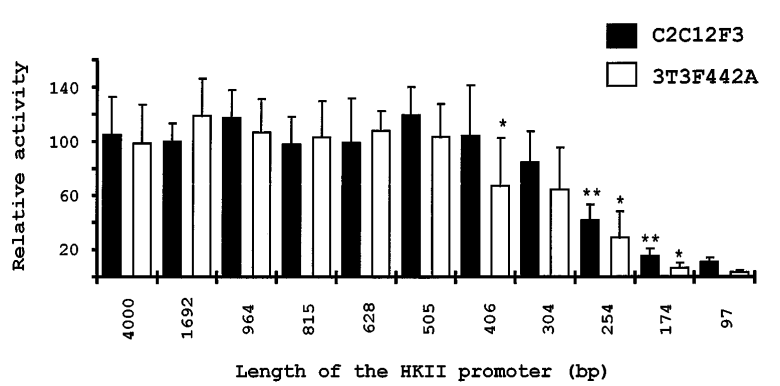

Fig. 4. Functional analysis of the human HKII promoter. $\mathrm{C} 2 \mathrm{C} 12 \mathrm{~F} 3$ myoblasts and 3T3F442A preadipocytes were transiently transfected with different HKII 5 ' deletion-luciferase fusion constructs. $\mathrm{C} 2 \mathrm{C} 12 \mathrm{~F} 3$ cells were harvested $40 \mathrm{~h}$ after transfection and 3T3F442A cells were harvested 4 days after differentiation into adipocytes. Cell lysates were assayed for luciferase and $\beta$-galactosidase activities. Luciferase activity was first corrected for background activity of the PXP1-vector and then normalized with $\beta$-galactosidase activity to correct for differency in transfection efficiency. The data represent mean \pm SEM of six independent experiments. Duplicate transfections were performed in each experiment with two to three different plasmid preparations. The activity of the -1692 HKII construct was set at $100 \%$. $* p<0.01$, ** $p<0.001$ (Student's $t$-test) indicate statistically significant losses in activity resulting from the deletion of any one segment of the promoter

expression of the luciferase reporter gene were tested for activity by transient transfection of the murine C2C12F3 skeletal muscle and 3T3F442A adipocyte cell lines. Both cell lines have been shown to express endogenous HKII upon differentiation [5]. Relative HKII promoter activities of the nested deletions, shown in Figure 4, were found to be similar in both cell lines. In $\mathrm{C} 2 \mathrm{C} 12 \mathrm{~F} 3$ cells, deleting the promoter region from $-4000 \mathrm{bp}$ to $-304 \mathrm{bp}$ resulted in no statistically significant decrease in activity. Therefore, the activity of the -1692 construct was set as $100 \%$ (Fig. 4). Deletion from -304 bp to -254 bp resulted in loss of approximately $60 \%$ of activity, deletion to $-174 \mathrm{bp}$ further loss of $25 \%$ of activity, and deletion to $-97 \mathrm{bp}$ resulted in additional loss of $5 \%$ of activity. This indicates that the CCAAT and Y-boxes together with the two Sp-1 elements located within this $174 \mathrm{bp}$ region are not sufficient to support maximal basal promoter activity. The activity of the HKII promoter in 3T3F442A cells differed from that in $\mathrm{C} 2 \mathrm{C} 12 \mathrm{~F} 3$ in that deletion of the region between $-505 \mathrm{bp}$ and $-406 \mathrm{bp}$ resulted in approximately $35 \%$ decrease in tion +217$)$ and the $\mathrm{G} \rightarrow \mathrm{A}($ at position -1159$)$ polymorphism in the $5^{\prime}$ untranslated and promoter regions, respectively. Number of subjects in parenthesis

activity. It appears that the core promoter elements responsible for basal promoter activity in skeletal muscle and adipose cells are located within the proximal $400 \mathrm{bp}$ and $500 \mathrm{bp}$, respectively.

The sequence variants at positions -1159 and -1043 of the human HKII promoter, which we observed to be equally represented among NIDDM and normal subjects, are unlikely to have any functional impact since deletion of the region between -1692 and -964 did not alter activity of the proximal promoter.

An internal deletion extending from -184 to -215 was prepared from the -254 promoter construct. This deletion encompassed a highly GC-rich region that contains three consensus binding sites for Sp1, 2 for each of AP-2 and GCF and one for ODC-NF-1. Surprisingly, the activity of the promoter construct with this internal deletion was on average $1.46 \pm 0.53$ fold that of the full -254 construct (three independent transfections done in triplicate; $p=0.007$ ) when transfected into 3T3F442A adipocyte cells. However, this internal deletion had no effect on promoter activity in the $\mathrm{C} 2 \mathrm{C} 12 \mathrm{~F} 3$ cell line. This indicates that the deleted segment may contain sites of interaction with negative regulatory factors, such as ODC-NF-1, which is known to repress $\mathrm{Sp} 1$ activation of the ornithine decarboxylase promoter in a tissue-specific manner [44]. These results also indicate that the region between -254 and -215 contains important positive promoter elements since a major loss in activity was observed in deleting the promoter from -254 to -174 . Alternatively, the increase in activity associated with the internal deletion may have been the result of relocation of the -254 to -215 region closer to the transcription initiation site.

In conclusion, functional analysis of the human HKII promoter deletions indicates that two sets of positive regulatory sequence elements located between $304 \mathrm{bp}$ and $215 \mathrm{bp}$ from the major transcription start site account for approximately $80 \%$ of the basal HKII promoter activity. One set is located in the $5^{\prime}$ half and the other in the 3 ' half of this approximately $100 \mathrm{bp}$ segment, the sequence of which is highly conserved ( $88 \%$ identity) between human and rat. A putative CRE is located in this region. In addition, the highly GC-rich region between nucleotides -215 and -184 contains a negative regulatory element, at least in $3 \mathrm{~T} 3$ cells. 
Recently, activities of nested deletions of promoter constructs of the rat HKII were analysed by transfection of rat L6 myotubes [48]. In contrast to the human HKII promoter, maximal basal activity of the proximal rat promoter in L6 myotubes was achieved by constructs containing only $157 \mathrm{bp}$. A similar length of the human promoter had only $15 \%$ activity in C2C12F3 cells.

Activity of the proximal HKII promoter in response to insulin and glucose. We investigated whether insulin or glucose would induce activity of the HKII promoter by transient transfection of $\mathrm{C} 2 \mathrm{C} 12 \mathrm{~F} 3$ and 3T3F442A cells with luciferase vectors containing 964, 406, 304, 174 and 97 bp (and one containing $4.0 \mathrm{~kb}$ in case of 3T3F442A) of the proximal HKII promoter as described under Materials and methods. Small (less than 1.5-fold) and variable inductive effects of insulin and glucose were observed which could not be used to localize insulin response elements. The steady-state level of HKII mRNA increased by only two-fold upon treatment of 3T3F442A cells with insulin using the same protocol used in transfection experiments (data not shown).

This result was unexpected since insulin was previously shown to increase the steady-state levels of HKII mRNA by six- and three-fold in fully differentiated $3 \mathrm{~T} 3 \mathrm{~F} 442 \mathrm{~A}$ and $\mathrm{C} 2 \mathrm{C} 12$ cells, respectively [5]. However, it was not determined whether insulin had any effect on the transcription rate of the HKII gene in these cell lines. In vivo, hyperinsulinaemia was observed to be associated with elevated HKII mRNA levels in rat skeletal muscle and adipose tissue [12], and in human skeletal muscle [13]. On the other hand, hyperglycaemia was not found to influence HKII expression in these tissues in the rat [12].

Our results suggest that either the insulin and glucose response elements are located outside of the 4.0 $\mathrm{kb}$ region of the proximal promoter, or that the cell lines we transfected were not sufficiently differentiated to give a significant response.

Various cis-acting sequences that mediate insulindependent regulation of transcription have been reported in promoters of genes encoding phosphoenolpyruvate carboxykinase (PEPCK)[45], c-fos [51, 52], amylase [53], glyceraldehyde 3-phosphate dehydrogenase (GAPDH) [54, 55], glugacon [56, 57], malic enzyme [58], delta 1-crystallin [59], prolactin [60], $\beta$-actin [61], insulin-like growth factor I-binding protein [62], tyrosine aminotransferase [46], thyrotropin receptor [63] and fatty acid synthase [64]. There seems to be no unique sequence found so far to mediate the effects of insulin. Two putative sequences found in the promoter of HKII gene resemble insulin responsive sequences found in other genes [51-64]. However, neither of these sites is totally conserved between human and rat.
Osawa et al. [65] recently observed that insulin induced by 3.5 -fold the activity of a reporter gene driven by $487 \mathrm{bp}$ of the proximal rat HKII promoter transfected into rat L6 myotubes but did not define the insulin response elements within this construct. Interestingly, these authors also showed that the induction of HKII by insulin was blocked by treatment with either wortmannin or rapamycin, suggesting that a phosphatidylinositol 3-kinase (PI 3-kinase)/ $\mathrm{p} 70 / \mathrm{p} 85$ ribosomal $\mathrm{S} 6$ protein kinase $\left(\mathrm{p} 70^{\mathrm{s} 6 \mathrm{k}}\right)$-dependent pathway may transduce the action of insulin on HKII gene expression. In addition, both insulin and glucose were shown to activate the rat HKII promoter $(4.3 \mathrm{~kb})$ in transient transfection of AS-30D hepatoma cells [23].

More reliable analysis of the level at which the HKII gene is regulated by glucose and insulin in various tissues and of the cis-DNA elements that mediate response to these agents in vivo would best be accomplished using transgenic mice that harbour various lengths of the HKII promoter driving expression of a reporter gene.

Acknowledgements. This work was supported by NIH grant HL-30 086 to S. D. and by a grant from the Nordisk Insulinfond to M.L. and M.M.

\section{References}

1. Wilson JE (1995) Hexokinases. Rev Physiol Biochem Pharmacol 126: 95-198

2. Katzen HM, Schimke RT (1965) Multiple forms of hexokinase in the rat: tissue distribution, age dependency and properties. Proc Natl Acad Sci USA 54: 1218-1225

3. Katzen HM (1967) Multiple forms of mammalian hexokinase and their significance in the action of insulin. Adv Enzyme Regul 5: 335-355

4. Katzen HM, Soderman DD, Cirillo VJ (1968) Tissue distribution and physiological significance of multiple forms of hexokinase. Ann NY Acad Sci 151: 351-358

5. Printz RL, Koch S, Potter LR, O'Doherty RM, Tiesinga SM, Granner DK (1993) Hexokinase II mRNA and gene structure, regulation by insulin and evolution. J Biol Chem 268: 5209-5219

6. Thelen AP, Wilson JE (1991) Complete amino acid sequence of the type II isoenzyme of rat hexokinase, deducted from the cloned cDNA. Arch Biochem Biophys 286: 645-651

7. Deeb SS, Malkki M, Laakso M (1993) Human hexokinase II: sequence and homology to other hexokinases. Biochem Biophys Res Comm 197: 68-74

8. Malkki M, Laakso M, Deeb SS (1994) Structure of the human hexokinase II gene. Biochem Biophys Res Comm 205: 490-496

9. Printz RL, Ardehali H, Koch S, Granner DK (1995) Human hexokinase II mRNA and gene structure. Diabetes 44: 290-294

10. Lehto M, Xiang K, Stoffel M et al. (1993) Human hexokinase II: localization of the polymorphic gene to chromosome 2. Diabetologia 36: 1299-1302

11. Osawa H, Printz RL, Whitesell RR, Granner DK (1995) Regulation of hexokinase II gene transcription and glucose 
phopshorylation by catecholamines, cyclic AMP, and insulin. Diabetes 44: 1426-1432

12. Postic C, Leturque A, Rencurel F et al. (1993) The effect of hyperinsulinaemia and hypergylcaemia on GLUT 4 and hexokinase II mRNA and protein in rat skeletal muscle and adipose tissue. Diabetes 42: 922-929

13. Mandarino LJ, Printz RL, Cusi KA et al. (1995) Regulation of hexokinase II and glycogen synthase mRNA, protein, and activity in human muscle. Am J Physiol 269:E701E708

14. Braithwaite SS, Plazuk B, Colca JR, Edwards II CW, Hoffman C (1995) Reduced expression of hexokinase II in insulin-resistant diabetes. Diabetes 44: 43-48

15. Rothman D L, Shulman R G, Shulman GI (1992) ${ }^{31}$ P magnetic resonance measurement of muscle glucose 6-phosphate. Evidence for reduced insulin-dependent muscle glucose transport or phosphorylation activity in non-insulindependent diabetes mellitus. J Clin Invest 89: 1069-1075

16. Granner DK, O’Brien R M (1992) Molecular physiology and genetics of NIDDM. Importance of metabolic staging. Diabetes Care 15: 369-395

17. Vestergaard H, Bjorbaek C, Hansen T, Larsen FS, Granner DK, Pedersen O (1995) Impaired activity and gene expression of hexokinase II in muscle from non-insulin-dependent diabetes mellitus patients. J Clin Invest 96: 2639-2645

18. Echwald SM, Bjorbaek C, Hansen T et al. (1995) Identification of four amino acid substitutions in hexokinase II and studies of relationships to NIDDM, glucose effectiveness, and insulin sensitivity. Diabetes 44: 347-353

19. Vidal-Puig A, Printz RL, Stratton IM, Granner DK, Moller DE (1995) Analysis of the hexokinase II gene in subjects with insulin resistance and NIDDM and detection of $\mathrm{Gln}^{142}$ - > His substitution. Diabetes 44: 340-346

20. Laakso M, Malkki M, Deeb SS (1995) Amino acid substitutions in hexokinase II among patients with NIDDM. Diabetes 44: 330-334

21. Lehto M, Huang X, Le Beau MM et al. (1995) Human hexokinase II gene: exon-intron organization, mutation screening in NIDDM, and its relationship to muscle hexokinase activity. Diabetologia 38: 1466-1474

22. Ichihara J, Shinohara Y, Kogure K, Terada H (1995) Nucleotide sequence of the $5^{\prime}$-flanking region of the rat type II hexokinase gene. Biochim Biophys Acta 1260: 365-368

23. Mathupala SP, Rempel A, Pedersen L (1995) Glucose catabolism in cancer cells. Isolation, sequence and activity of the promoter for type II hexokinase. J Biol Chem 270: 16918-16925

24. Nakashima RA, Paggi MG, Scott LJ, Pedersen PL (1988) Purification and characterization of a bindable form of mitochondrial bound hexokinase from the highly glycolytic AS-30D rat hepatoma cell line. Cancer Res 48: 913-919

25. Sambrook J, Fritsch EF, Maniatis T (1989) Molecular cloning. A laboratory manual. 2nd edn. Cold Spring Harbor Laboratory Press, Cold Spring Harbor, NY pp 7.79-7.83

26. Chomczynski P, Sacchi N (1987) Single step method of RNA isolation by acid guanidium thiocyanate-phenolcholoroform extraction. Anal Biochem 162: 156-159

27. Laakso M, Malkki M, Kekäläinen P, Kuusisto J, Deeb SS (1995) Polymorphisms of the human hexokinase II gene: lack of association with NIDDM and insulin resistance. Diabetologia 38: 617-622

28. DeWet JR, Wood KV, De Luca M, Helinski DR, Subramani S (1987) Firefly luciferase gene: structure and expression in mammalian cells. Mol Cell Biol 7: 725-737

29. Nordeen SK (1988) Luciferase reporter gene vectors for analysis of promoters and enhancers. Biotechniques 6: 454-458
30. Rastinejad F, Blau H (1993) Genetic complementation reveals a novel regulatory role for 3 ' untranslated regions in growth and differentiation. Cell 72: 903-917

31. Green H, Kehinde O (1976) Spontaneous heritable changes leading to increased adipose conversation in 3T3 cells. Cell 7: 105-113

32. Bradford M (1976) A rapid and sensitive method for the quantitation of microgram quantities of protein utilizing the principle of protein-dye binding. Anal Biochem 72: 248-254

33. Yang W-S, Nevin DN, Peng R, Brunzell JD, Deeb SS (1995)Mutation in the promoter of the lipoprotein lipase (LPL) gene in a patients with familial combined hyperlipidemia and low LPL activity. Proc Natl Acad Sci USA 92: 4462-4466

34. Dynan WS, Tjian R (1983)The promoter-specific transcription factor $\mathrm{Sp} 1$ binds to upstream sequences in the SV 40 early promoter. Cell 25: 79-87

35. Jones KA, Kadonaga JT, Rosenfeld PJ, Kelly TJ, Tjian R (1987) A cellular DNA binding protein that activates eukaryotic transcription and DNA replication. Cell 48: 79-89

36. Mitchell P, Wang C, Tjian R (1987) Positive and negative regulation in vitro: enhancer-binding protein AP-2 is inhibited by SV-40 T antigen. Cell 50: 847-861

37. Faisst S, Meyer S (1992) Compilation of vertebrate-encoded transcription factors. Nucl Acids Res 20: 3-26

38. Kageyama R, Pastan I (1989) Molecular cloning and characterization of a human DNA binding factor represses transcription. Cell 59: 815-825

39. Dorn A, Bollekens J, Staub A, Benoist C, Mathis D (1987) A multiplicity of CCAAT-box binding proteins. Cell 50: 863-872

40. Szabo SJ, Gold J, Murphy TL, Murphy KM (1993) Identification of cis-acting regulatory elements controlling interleukin-4 gene expression in T cells: roles for NF-Y and NF-ATc. Mol Cell Biol 13: 4793-4805

41. Framson P, Bornstein P (1993) A serum response element and a binding site for NF-Y mediate the serum response of the human thrombospondin 1 gene. J Biol Chem 268: 4989-4996

42. Ronchi A, Bellorini M, Mongelli N, Mantovani R (1993) CCAAT box binding protein NF-Y (CBS,CP1) recognizes the minor groove and distorts DNA. Nucl Acid Res 23: 4565-4572

43. Glimcher LH, Kara CJ (1992) Sequences and factors: a guide to MHC class-II transcription. Annu Rev Immunol 10: $13-49$

44. Li R-S, Abrahamsen MS, Johnson RR, Morris DR (1994) Complex interactions at a GC-rich domain regulate cell type-dependent activity of the ornithine decarboxylase promoter. J Biol Chem 269: 7941-7949

45. Forest CD, O'Brien RM, Lucas PC, Magnuson MA, Granner DK (1990) Regulation of phosphoenolpyruvate carboxykinase gene expression by insulin. Use of stable transfection approach to locate an insulin responsive sequence. Mol Endocrin 4: 1302-1310

46. Ganss R, Weih F, Schutz G (1994) The cyclic 3' 5'- monophosphate- and the glucocorticoid-dependent enhancers are targets for insulin repression of tyrosine aminotransferase gene transcription. Mol Endocrin 8: 895-903

47. O'Brien RM, Lucas PC, Yamasaki T, Noisin EL, Granner DK (1994) Potential convergence of insulin and cAMP signal transduction systems at the phosphoenolpyruvate carboxykinase (PEPCK) gene promoter through CCAAT/enhancer protein (c/ebp). J Biol Chem 269: 30419-31428

48. Osawa H, Sutherland C, Robey RB, Printz RL, Granner DK (1996) Identification and characterization of basal and 
cyclic AMP response elements in the promoter of the rat hexokinase II gene. J Biol Chem 271: 17296-17303

49. Batzer M A, Deininger PL, Hellman-Blumberg U et al. (1996) Standardized nomenclature for Alu repeats. J Mol Evol 42: 3-6

50. Kapitonov V, Jurka JJ (1996) The age of Alu subfamilies. J Mol Evol 42: 59-65

51. Stumpo DJ, Stewart TN, Gilman MZ, Blackshear PJ (1988) Identification of c-fos sequences involved in induction by insulin and phorphol esters. J Biol Chem 264: 1611-1614

52. Messina JL (1990) Insulin's regulation of c-fos gene transcription in hepatoma cells. J Biol Chem 165: 11700-11705

53. Johnson TM, Rosenberg MP, Meisler MH (1993) An insulin-responsive element in the pancreatic enhancer of the amylase gene. J Biol Chem 268: 464-468

54. Nasrin N, Ercolani L, Denaro M, Kong XF, Kang I, Alexander M (1990) An insulin responsive element in the glyceraldehyde-3-phosphate dehydrogenase gene binds a nuclear protein induced by insulin in cultured cells and by nutritional manipulations in vivo. Proc Natl Acad Sci USA 87: $5273-5277$

55. Alexander-Bridges M, Dugast I, Ercolani L, Kong XF, Giere L, Nasrin N (1992) Multiple insulin-responsive elements regulate transcription of the GAPDH gene. Adv Enz Reg 32: 149-159

56. Knepel W, Jepeal L, Habener JF (1990) A pancreatic islet cell-specific enhancer-like element in the glucagon gene contains two domains binding distinct cellular proteins. J Biol Chem 265: 8725-8735

57. Philippe J, Morel C, Cordier-Bussat M (1995) Islet specific proteins interact with the insulin-responsive element of the glucagon gene. J Biol Chem 270: 3039-3045
58. Garcia-Jimenez C, Benito B, Jolin T, Santisteban P (1994) Insulin regulation of malic enzyme gene expresison in rat liver: evidence for nuclear proteins that bind to two putative insulin response elements. Mol Endocrin 8: 1361-1369

59. Alemany J, Borras T, De Pablo F (1990) Transcriptional stimulation of the crystallin gene by insulin-like growth factor I and insulin requires DNA cis elements in chicken. Proc Natl Acad Sci USA 87: 3353-3357

60. Stanley FM (1992) An element in the prolactin promoter mediates the stimulatory effect of insulin on transcription of the prolactin gene. J Biol Chem 267: 16719-16726

61. Onyia JE, Halladay DL, Messina JL (1995) One of the three CCarGG box/serum response elements of the $\beta$-actin gene is an insulin-responsive element. Endocrinology 136: 306-315

62. Suwanickul A, Morris SL, Powell DR (1993) Identification of an insulin-responsive element in the promoter of the human gene for insulin-like growth factor binding protein-1. J Biol Chem 268: 17063-17068

63. Shimura Y, Shimura H, Ohmori M, Ikuyama S, Kohn LD (1994) Identification of a novel insulin-responsive element in the rat thyrotropin receptor promoter. J Biol Chem 269: 31908-31914

64. Moustaid N, Beyer RS, Su HS (1994) Identification of an insulin responsive element in the fatty acid synthase promoter. J Biol Chem 269: 5629-5634

65. Osawa H, Sutherland C, Robey RB, Printz RL, Granner DK (1996) Analysis of signalling pathway involved in the regulation of hexokinase II gene transcription by insulin. $\mathbf{J}$ Biol Chem 271: 16690-16694 